\title{
Gastrointestinal Issues in Critical Care
}

Editors

RAHUL S. NANCHAL

RAM M. SUBRAMANIAN

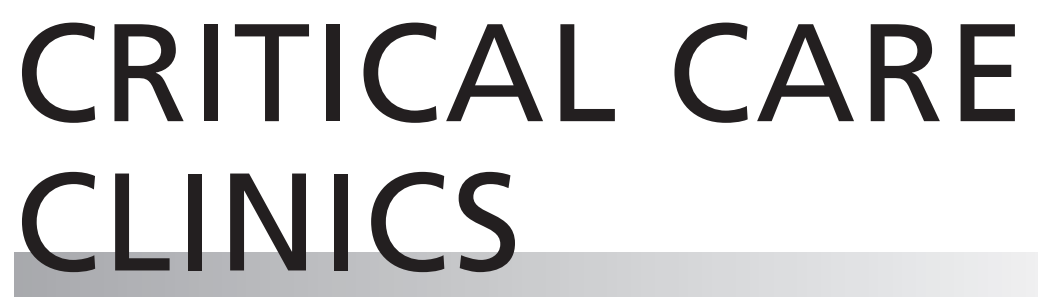

www.criticalcare.theclinics.com

Consulting Editor

RICHARD W. CARLSON

April 2016 - Volume 32 - Number 2 